\title{
Escravismo
}




\title{
Liberalismo e escravidão
}

\author{
ENTREVISTA COM JACOB GORENDER
}

$\mathrm{N}$ O PRÓximo dia 20 de janeiro de 2003, o historiador Jacob Gorender completa 80 anos de idade. Nascido em Salvador (BA) em 1923, é autor de dois clássicos da historiografia brasileira: O escravismo colonial (São Paulo, Editora Ática, 1978; $6^{a}$ ed., 1992) e Combate nas trevas (São Paulo, Editora Ática, 1987; 6 a ed., 1999). Foi professor visitante do Instituto de Estudos Avançados da USP (1994-96), vencedor do concurso "Intelectual do Ano" da União Brasileira de Escritores em 2000 e, em 1992, recebeu o título de Doutor Honoris Causa pela Universidade Federal da Bahia.

Entre outras obras, publicou: A burguesia brasileira (1981), Gênese e desenvolvimento do capitalismo no campo brasileiro (1987), A escravidão reabilitada (1990), O fim da URSS. Origens e fracasso da perestroika (1991), Marcino e Liberatore (1992), Marxismo sem utopia (1999) e Brasil em preto \& branco: o passado escravista que não passou (2000).

O texto que aqui se publica - transcrição de entrevista dada a ESTUDOS AVANCSADOS em 19 de setembro de 2002 - foi revisto pelo entrevistado.

\section{Liberalismo e escravidão}

ESTUDOS AVANÇADOS - Por que a política econômica que regeu o Brasil a partir da abertura dos portos (1808) pode ser considerada estruturalmente liberal? O que levou D. João e seu conselheiro José da Silva Lisboa a abrir a economia ao mercado internacional?

Jacob Govender - Quero de início precisar que a economia anterior e posterior à abertura dos portos, até o fim do século XIX, é definida por mim como economia escravista colonial. Ou seja, por seu caráter objetivo, deve ser definida como modo de produção escravista colonial.

Naquele momento, porém, já havia chegado ao Brasil a influência da teoria econômica liberal que dominou a Inglaterra no século XVIII e que teve seu expoente em Adam Smith. Essa influência também vinha da Revolução Francesa, a qual deu fundamento ao lema Laissez faire, laissez passer, à liberdade de transação, de produção e circulação. A teoria liberal surgiu e se fortaleceu na Europa em contraposição aos cânones feudais da monarquia absolutista e isso se fez sentir também no Brasil.

Os plantadores brasileiros e os comerciantes radicados no Brasil se mostraram receptivos a essa pregação de política econômica liberal. E, no caso, José da 
Silva Lisboa foi coerente com essas idéias, conhecedor que era de Adam Smith. Quando esteve com o príncipe regente João de Bragança, no momento em que este aportou em Salvador, recomendou a abertura dos portos brasileiros.

Devo observar que a abertura dos portos já vinha sendo uma reivindicação bem anterior. Havia uma pressão dos plantadores e comerciantes residentes no Brasil pelo rompimento com o monopólio português.

Portugal cumpria um papel meramente de intermediário, era um consumidor de importância secundária dos produtos brasileiros. O que os comerciantes portugueses e a Coroa faziam consistia em intermediar, receber os produtos brasileiros e depois redistribuí-los no mercado europeu. Portugal, nessa altura, era uma metrópole ineficiente, fraca, cujo monopólio deixara de convir aos interesses dos plantadores e comerciantes. Já havia antes da abertura dos portos um grande contrabando de mercadorias inglesas, que entravam no Brasil, à margem do monopólio lusitano. Navios ingleses não tinham dificuldade de chegar ao Brasil e vender suas manufaturas, que encontravam compradores aqui. A reivindicação era que cessassem as limitações legais e o comércio se fizesse livremente, o que interessava à Inglaterra, que fazia pressão para a abertura dos portos. Quando veio o ato do príncipe regente, correspondeu a uma pressão que ocorria anteriormente e se concretizou a partir daí.

A influência das idéias liberais européias chegou ao Brasil e se adequou a interesses aqui radicados, expressos naquela circunstância pelo futuro visconde de Cayru.

Estudos AVANÇADOS - Por que o liberalismo político formal (constitucional) foi parte integrante do sistema político brasileiro a partir da Independência? Pode-se sustentar a tese de que as idéias liberais esposadas pelos donos do poder estariam "fora do lugar" no Brasil do século XIX?

Jacob Govender - A partir desse ato, tenho também que acrescentar o seguinte: a própria Independência do Brasil foi alcançada levantando a bandeira dos princípios liberais, ou seja, da liberdade política. O que os plantadores e os comerciantes reivindicavam era o direito de serem representados no Estado, quer dizer, de terem o seu próprio Estado, que eles próprios controlassem, e não mais fosse uma peça da política colonial, como vinha sendo.

Essa reivindicação, fundamental no caso da Independência, foi obtida em 1822, de maneira incompleta, porque na cabeça do Estado, que então se organizou, estava Pedro I que, além de português, era voltado aos interesses dinásticos em Lisboa. Como se sabe, depois que saiu do Brasil em 1831, veio a ser Pedro IV em Portugal. O Brasil era apenas um trampolim, um degrau para que ele chegasse ao trono de Lisboa. Já a classe dominante escravista no Brasil queria um Estado todo dela, no qual fosse perfeitamente representada. Por isso, políticos brasileiros como José Bonifácio, José Clemente Pereira, Gonçalves Ledo eram constitucionalistas. A Constituição era a bandeira desses políticos, porque representava 
a sua defesa contra um príncipe que não era brasileiro, e que também não estava inteiramente interessado nas pretensões da classe dominante do Brasil.

A Independência se completa e o Estado se nacionaliza realmente em 1831, quando Pedro I abdica e vai embora. Aí temos o Estado brasileiro completamente nacionalizado e compatível com os interesses da classe dominante brasileira.

Não posso considerar que as idéias liberais estivessem fora do lugar. Pareceme que elas estavam no lugar certo. É evidente que o liberalismo no Brasil não podia ter a mesma feição que tinha na Inglaterra. E não se podia esperar que essas idéias nascessem de autores brasileiros, evidentemente estes apreenderam tais idéias formatadas fora do Brasil. Mas eles as escolheram, elas não vieram aleatoriamente ao Brasil e não tiveram efeitos inexplicáveis, arbitrários e deslocados. Estavam no lugar apropriado, reproduziram o que seus defensores pretendiam. Particularmente, o visconde de Cayru e também outros políticos brasileiros que já citei.

Assim, o sistema político brasileiro a partir da Independência passa a incorporar as idéias liberais de liberdade de comércio e de representação política para a classe dominante brasileira.

Quero acrescentar que, no momento em que o futuro visconde de Cayru recomenda a abertura dos portos, Portugal estava ocupado com o Exército de Napoleão. A abertura dos portos era algo que tinha de acontecer. Concordasse o príncipe ou não. Ele não tinha como recuar disso, porque Portugal naquele momento estava impotente e inerme, dominado pelo Exército napoleônico.

Estudos AVANÇADOS - Como o liberalismo se ajustou estruturalmente ao escravismo?

Jacob Gorender - Em tese, o liberalismo europeu defendeu o trabalho livre, o mercado de trabalho de assalariados juridicamente livres. Defendeu a eliminação das injunções feudais, do pagamento da corvéia; enfim, de todos os tributos característicos do sistema feudal. Mas é preciso lembrar que o próprio Adam Smith não era contra a escravidão nas colônias. Ou seja, o próprio liberalismo europeu já nasceu sob esta contradição; mesmo a Revolução Francesa decretou a libertação dos escravos nas colônias francesas em 1794, mas Napoleão restabeleceu a escravidão oito anos depois.

Ou seja, o próprio liberalismo, inglês ou francês, padeceu dessa contradição, que talvez não seja uma contradição entre o liberalismo e o escravismo, mas somente uma incorporação do escravismo como integrante de um sistema colonial. Trabalho livre na Europa, escravidão nas colônias americanas - tal a ordenação segmentada, estabelecida pela teoria liberal. Note-se que Thomas Jefferson, um dos principais líderes da emancipação dos Estados Unidos, foi o redator da declaração da Independência, segundo a qual todos os homens são iguais. No entanto, Jefferson era grande proprietário de escravos e não via nisso incoerência, pois julgava os negros pertencentes a uma raça de inteligência inferior. 


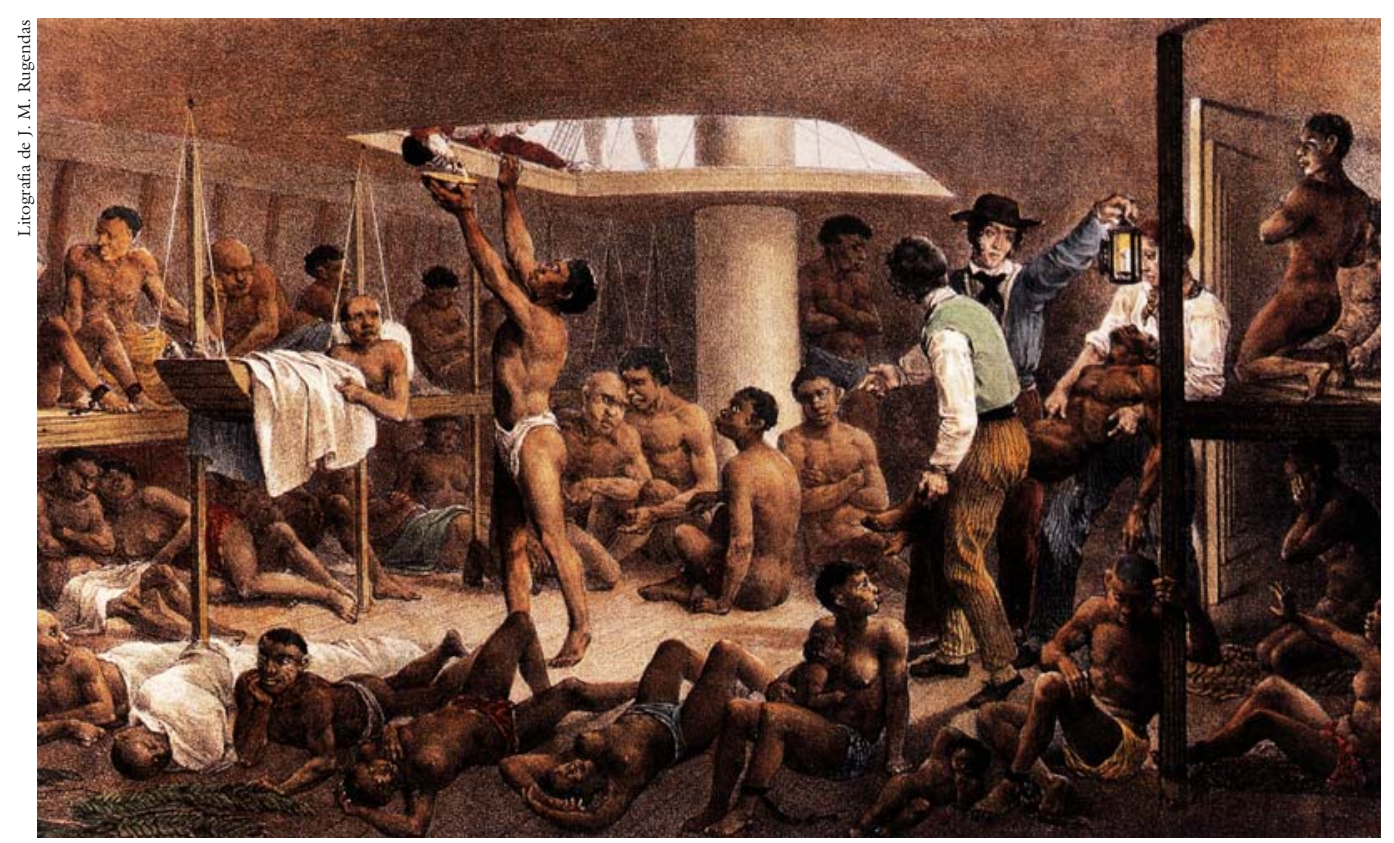

Negros no fundo do porão de navio (1835)

Por fim, mais antigo que o liberalismo europeu é o cristianismo, que também conviveu com a escravidão. Ela está não só no Velho Testamento (os judeus tinham escravos, inclusive outros judeus) como está no Novo Testamento: Paulo, o apóstolo, considerava a escravidão justa quando de acordo com certas regras. E aqui, no Brasil, a verdade é que o cristianismo se coadunou com a escravidão, distinguindo-se ao pregar a moderação no trato dos escravos. O que os jesuítas, em particular, e outras ordens fizeram aqui no Brasil foi pregar a moderação: não se exceder na extração do trabalho escravo e particularmente nos castigos. O que tinha o significado de legitimação da instituição escravista.

\section{A questão da família escrava}

ESTUDOS AVANÇADOS - Que viabilidade o regime escravista concedeu à família dos cativos e à reprodução da população escrava?

Jacob Govender - Queria partir de uma tese que, tendo uma difusão na historiografia sobre a escravidão a partir de Gilberto Freyre, sobretudo em Casa Grande e Senzala, procurou nobilitar a origem racial brasileira, esforçando-se para demonstrar que a componente africana não deveria ser considerada depreciativamente. É um mérito dele. Mas, ao mesmo tempo, como sabemos, Freyre defendeu uma série de teses em sua obra que deram margem, logo em seguida, à idéia da existência de uma democracia racial brasileira já na época da escravidão. Além disso, conquanto procurasse dignificar a componente africana, empenhouse em demonstrar que a vida cotidiana dos escravos era dominada pela promiscuidade. Não há vestígios de família escrava em sua obra. O que há é a família patriarcal dos senhores. Esta, sim, é colocada no pedestal, inclusive como matriz da formação social brasileira. 


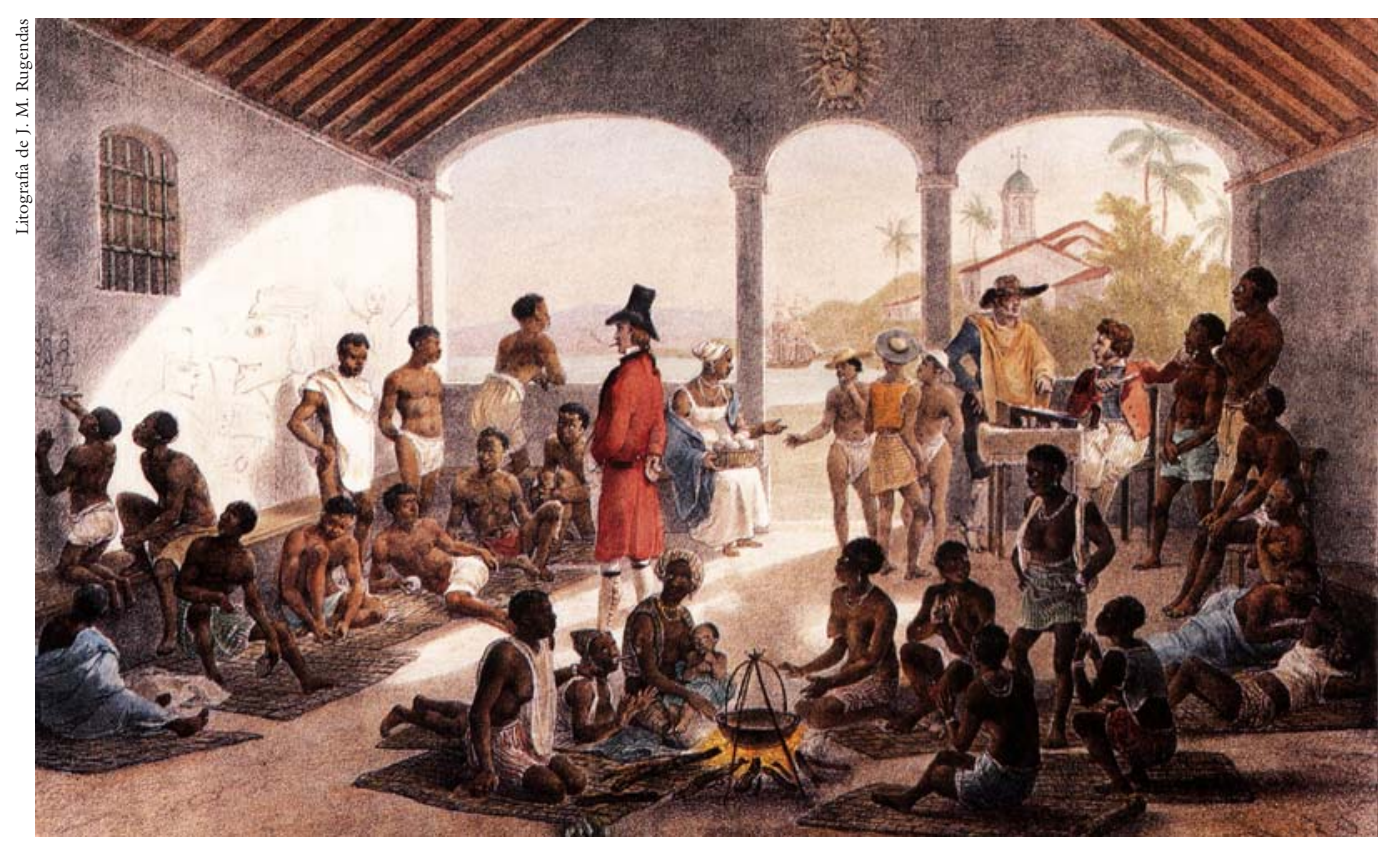

Mercado de escravos

Tal visão sobre a vida promíscua dos escravos africanos, com ausência da instituição da família, foi encampada por críticos de Freyre, em sua maioria historiadores e sociólogos paulistas. A verdade é que Florestan Fernandes, Roger Bastide e Emília Viotti da Costa também defenderam essa visão. A historiadora baiana Kátia Mattoso a expôs de maneira extrema, levando-a ao absoluto. Florestan, por sua vez, ressaltou o que chamou de estado de anomia no meio escravo.

O que se dá, então, é que, posteriormente, os estudos sobre a família de certo modo floresceram na historiografia. Historiadores como Iraci del Nero da Costa, da Faculdade de Economia da USP e Robert Slenes, da Unicamp, obtiveram dados documentais sobre famílias estáveis no meio escravo, as quais formavam redes de parentesco e que se prolongavam no tempo, passando de uma geração a outra. Assim, quando encontravam condições favoráveis, evidenciou-se que os escravos optavam pela constituição de famílias estruturadas e repeliam a promiscuidade sexual.

Contudo, os dados documentais coligidos a respeito limitam-se até agora à cafeicultura paulista no Vale do Paraíba e a uma fase de prosperidade e de expansionismo da plantagem escravista, durante o século XIX. Era, então, do interesse dos senhores escravistas não só manter, como aumentar os plantéis de escravos. Não seria contrário aos interesses deles que os escravos formassem famílias dotadas de estabilidade. Por parte da Igreja, sempre houve o interesse de sacramentar a instituição do casamento entre escravos do ponto de vista religioso, desde o tempo colonial. Tanto quanto possível, isso devia operar para a estabilidade matrimonial entre os escravos ou, pelo menos, não operava em sentido contrário. 
De todo modo, faltam dados sobre a família em outras situações, isto é, fora da área cafeicultora e numa fase de prosperidade. A meu ver, do ponto de vista geral, a escravidão operou funcionalmente contra a existência da família, e em sentido contrário a uma reprodução vegetativa positiva.

Esse fato não é incriminado pela descoberta de famílias estáveis numa certa, determinada e específica situação. Trata-se de questão historiográfica controversa.

ESTUDOS AVANÇADOS - Quais são os historiadores que julgam que não havia a instituição familiar? O senhor concorda com essa tese? Porque entendo que o senhor acha que não havia instituição familiar a não ser em raros momentos de prosperidade.

Jacob Govender - Uma família estável e com a incidência relevante apontada nesses estudos foi algo peculiar. Antes da cessação do tráfico africano, em 1850, a ocorrência de famílias escravas era ocasional; porém, se verificava. A negação total da existência da família escrava, como faz Kátia Mattoso, não corresponde à realidade factual. Esta negação total não é a minha posição.

ESTUDOS AVANÇADOS - E há historiadores que fizeram pesquisas nessa linha de encontrar núcleos familiares?

Jacob Govender - Devo mencionar Iraci del Nero da Costa, Robert Slenes, José Flávio Motta, Manolo Florentino e José Roberto Goés. São autores que pesquisaram a existência de famílias com redes de parentesco e conseguiram documentá-lo. Sempre no período de expansão do café. Não temos estudos sobre o tema com igual fundamento documental nas áreas do açúcar, algodão, tabaco e pecuária, a não ser informações incidentais.

ESTUDOS AVANÇADOS - Mas, segundo Gilberto Freyre, que conhecia a situação de Pernambuco na época do açúcar, não havia a instituição familiar? Ele nega a estabilidade familiar do escravo?

Jacob Govender - Ele não faz referência a famílias escravas. Freyre não se contrapunha explicitamente à tese da existência da família escrava. O que sobreleva no caso de Casa Grande e Senzala é a família patriarcal, a família dos senhores, que, segundo Freyre, teria sido a matriz da unidade nacional.

Entretanto, se não há referência às famílias escravas, há uma referência destacada à promiscuidade sexual. Os negros e as negras aparecem em atos sexuais promíscuos entre si e com os homens livres.

Em sua obra, isto é colocado como uma grande virtude brasileira, porque teria dado lugar à miscigenação racial. Freyre fez uma apologia das supostas propensões genésicas dos portugueses e da sua capacidade de se misturar com os povos de cor, o que já viria de antes até da descoberta do Brasil.

Essa questão da promiscuidade entre os escravos se transfere a outros autores historiadores e sociólogos, cuja posição se opôs à de Gilberto Freyre. São justamente historiadores e sociólogos paulistas, os quais expõem uma escravidão 
vil, dura e nada benéfica para os escravos. Posição contrária à do autor pernambucano, que sempre tendeu a fazer a apologia de uma escravidão dulcificada, que não teria sido tão má assim para os escravos.

Mas esses mesmos pesquisadores, contrários a Gilberto Freyre, se situam a seu lado, quando a questão se refere à promiscuidade sexual. Menciono-o porque os autores de estudos sobre a família escrava no meio cafeeiro também citam aqueles nomes. Tais autores apresentam-se como contestadores da tese da promiscuidade sexual. Seus estudos são meritórios, mas o que acontece é que ficaram restritos à área do café na primeira metade do século XIX.

ESTUDOS AVANÇADOS - Então é uma contestação verdadeira mas, por enquanto, parcial.

Jacob Gorender - E, sendo assim, ela não é convincente como tese geral!

ESTUDOS AVANÇADOS - São necessários novos estudos para completar nas outras áreas e lá saber qual era a situação da família escrava?

Jacob Govender - Na área do açúcar, do algodão, da mineração, e outras tantas, o que acontecia a respeito.

A contestação da promiscuidade baseada na existência da família escrava, assim como pretendem os autores citados, é insuficiente. Essa é a posição que defendo.

Para encerrar esta parte da nossa entrevista, queria me referir aos fatores contrários à existência de famílias e que não deixavam de empurrar para uma certa promiscuidade. O primeiro fator demográfico, característico do escravismo no Brasil, e em outras partes da América, foi o grande desequilíbrio sexual da população escrava, derivado do tráfico africano. Isto é incontestável: entravam muito mais escravos (masculinos) do que escravas.

A razão de masculinidade era muito alta. Temos usualmente perto de 200 ou 250 escravos para 100 escravas, nas grandes plantagens. Isto vinha predeterminado pelo tráfico transatlântico. O que se pode dizer, baseado em muitos testemunhos, é que os compradores e os plantadores que viriam a ser os exploradores do trabalho escravo, preferiam os homens, consideravam que estes eram mais eficientes. As mulheres eram preferidas no trabalho doméstico e em algumas tarefas produtivas da plantagem. Embora os homens escravos fossem mais caros, eles eram trazidos em maior quantidade para o Brasil.

O desequilíbrio sexual não podia deixar de influir na questão das famílias escravas. O que se observa, mesmo na área do café, é que, com os dados desses mesmos autores que falam da família escrava, no momento em que eles fazem a pesquisa, verificam que 70 e poucos por cento das mulheres estavam casadas ou viúvas (consorciadas), mas somente 30 e poucos por cento dos homens se achavam nessa condição. Está claro por que dois terços dos homens não encontrariam parceiras para o casamento. Tal fator era inibidor da existência de uma família escrava estável. 
Há outros dois fatores que influíram negativamente. Um foi o sistema brasileiro de habitação dos escravos nas senzalas. Homens e mulheres habitavam senzalas separadas, ao contrário do que acontecia nos Estados Unidos, onde cada família escrava tinha sua cabana própria. A habitação, separando os homens das mulheres, não poderia favorecer a estabilidade das famílias escravas. Obviamente, os encontros entre os casais se davam de maneira furtiva e aleatória.

Outro fator, não o último, é que a família escrava não tinha proteção legal. A lei permitia que a qualquer momento os casais e seus filhos pudessem ser separados pela venda. Foi só em 1871, com a chamada Lei do Ventre Livre (portanto, já no final do escravismo), que a legislação estabeleceu a inseparabilidade dos casais e dos filhos menores de 12 anos - os maiores podiam ser vendidos.

Creio ser evidente que o escravismo colonial, em toda a América, com exceção do Sul dos Estados Unidos, superou, de acordo com uma dinâmica desfavorável, a reprodução vegetativa da população escrava. Houve exceções faseológicas, mas a tendência geral foi a da dinâmica desfavorável. Daí que o Brasil (colonial e independente) foi, portanto, o maior absorvedor de africanos escravizados.

\section{Escravidão e modernidade no Oeste Paulista}

ESTUDOS AVANCADOS - Seria correta a tese da "modernidade do Oeste Paulista" como promotora do fim do trabalho escravo?

Jacob Gorender - A questão do Oeste Paulista surge como uma explicação muito significativa a respeito da superioridade de São Paulo (o grande Estado na economia brasileira, a locomotiva que puxa 20 vagões etc). Como explicar essa superioridade? A questão desafiou as modernas ciências sociais no meio acadêmico paulista.

Uma explicação veio do caráter excepcional, peculiar do Oeste Paulista, ou seja, da cafeicultura neste Oeste. Aí existiria a propensão dos plantadores pelo trabalho livre. Teriam sido pioneiros do emprego do trabalho livre, numa ecomomia tipicamente de plantação. Quem primeiro apresentou essa tese foi Sérgio Buarque de Holanda, em prefácio da obra do imigrante suíço Thomas Davatz, que trabalhou numa fazenda em Ibicaba e depois, voltando à Suíça, escreveu um relato sobre a experiência dele. Em Ibicaba houve um levante de colonos livres. No seu prefácio, Sérgio Buarque se referiu a uma nova raça de senhores, que teria propensão ao emprego do trabalho livre. Isso derivaria das peculiaridades da economia cafeeira, da nova situação que o Brasil atravessava, e assim por diante.

Essa tese foi desenvolvida por Fernando Henrique Cardoso, Octavio Ianni, Boris Fausto, Paula Beiguelman e Warren Dean. Este último, historiador americano que deu uma contribuição muito importante à historiografia brasileira $\mathrm{e}$ que viria a morrer tragicamente no Chile, envenenado por escapamento de gás. 
Paula Beiguelman fez uma distinção entre o Oeste Antigo (Campinas e arredores, Capivari, Atibaia etc.) e o Oeste Novo (municípios adjacentes à estrada de ferro Mojiana e da Paulista). A tese sobre as peculiaridades inovadoras dos plantadores refere-se mais fortemente ao Oeste Novo, cuja modernidade teria se antecipado à Abolição.

Contestei a tese da modernidade do Oeste Paulista no meu livro Oescravismo colonial. A consulta aos dados de produção e quantidade de escravos no suceder dos anos e aos dados da imigração me levou à conclusão de que, ao contrário do que esses autores supunham, os fazendeiros do Oeste Paulista (seja do Antigo, seja do Novo) eram também propensos, não ao trabalho livre, mas ao trabalho escravo. Isso, até a década de 80 do século XIX. Antes disso, procuraram, o mais possível, se basear na exploração do trabalho escravo, comprando escravos africanos; e, depois da cessação do tráfico africano, tornaram-se os maio-res importadores de escravos procedentes do Nordeste. Estes vieram para o Vale do Paraíba, mas também, em grande proporção, para o Oeste Paulista, onde o crescimento quantitativo dos escravos acabou superando o do Vale do Paraíba.

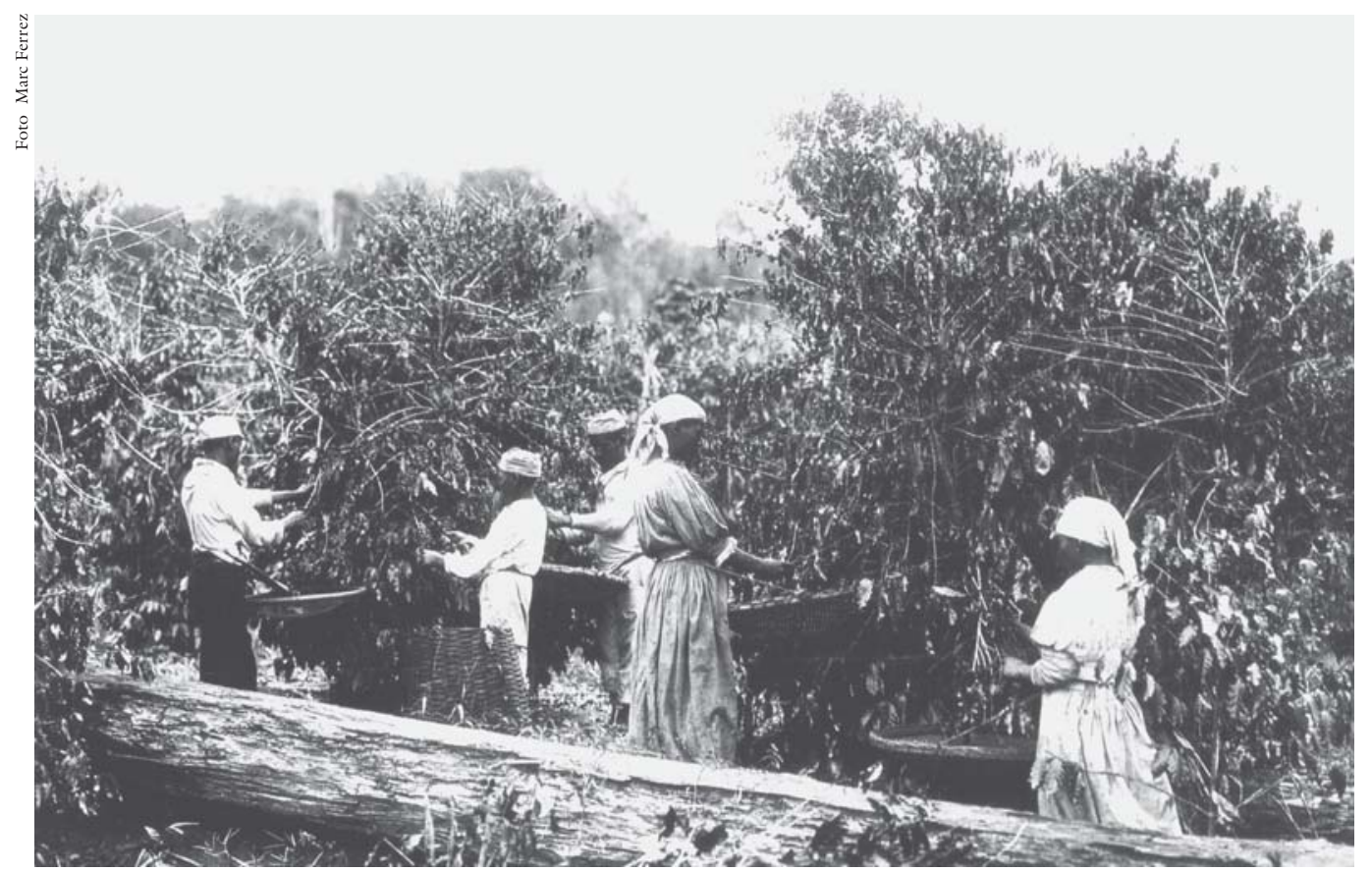

Negros na lavoura de café no século XIX

Os cafeicultores do Oeste Paulista eram modernos na implantação de equipamentos; utilizavam, por exemplo, ferrovias (inclusive particulares, intra e entre fazendas), empregavam o terreiro ladrilhado para a secagem do café, secadores acionavam-se mecanicamente etc. Mas, no que se refere ao trabalho, preferiam o escravo. Simplesmente porque a compra de um escravo era rotineira e garantida, ao passo que os trabalhadores livres ainda eram escassos e esquivos. 
O que vemos é que, enquanto Pernambuco se esvazia de escravos, o Oeste Paulista se enche deles. Foi o que aconteceu no século XIX. É na década de 1880 que os cafeicultores tornam-se propensos à imigração. A fuga de escravos estava aumentando sob a influência do abolicionismo, inclusive aqui em São Paulo, com Antônio Bento. Os escravos passaram a ser uma propriedade insegura, pois fugiam, encontravam apoio da população livre e se alojavam em Santos, onde não podiam ser alcançados.

Nesse ínterim, a posição do governo mudou. O governo paulista passou a subvencionar as despesas de passagem dos imigrantes europeus, livrando-os de dívidas extorsivas. A medida deu impulso à vinda em massa de imigrantes italianos e outros.

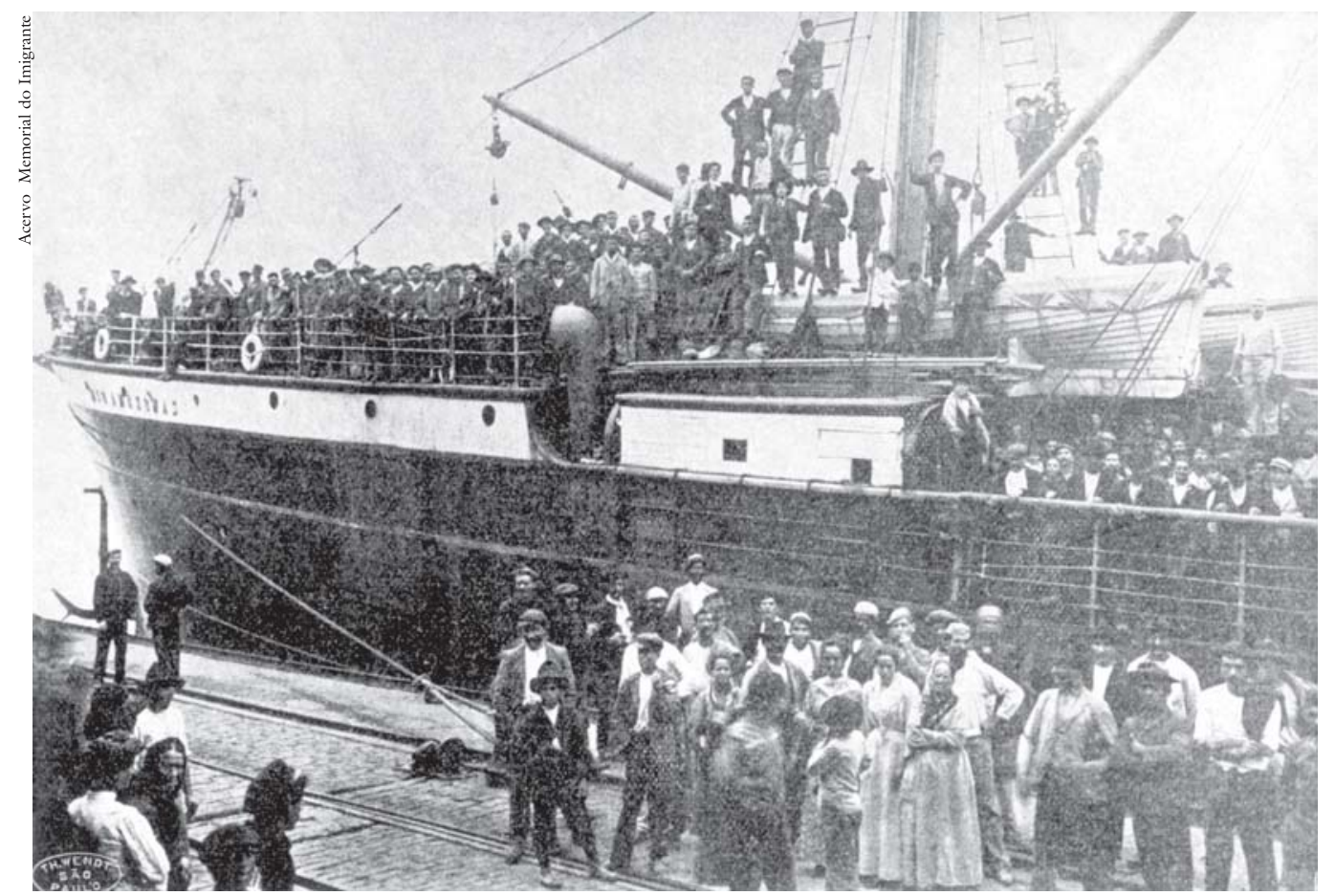

Desembarque de imigrantes no Porto de Santos (SP), 1907.

ESTUDOS AVANÇADOS - Alguns estudiosos weberianos acreditavam que havia uma certa propensão para a modernidade nesses "novos senhores", como os chama Sérgio Buarque de Holanda. Necessariamente, eles deveriam considerar o trabalho escravo como menos rentável. Aí está o equívoco? Não era porque fossem mais "modernizadores" que eles iriam propugnar por uma forma de trabalho que, naquela altura, ainda não fôra testada, ao passo que o trabalho escravo já era institucionalizado.

Jacob Govender - E havia ainda uma fonte abundante de escravos no Nordeste. Tratava-se de uma transação perfeitamente viável, objetiva e racional. Não é verdade que a escravidão não fosse racional, ou que derivasse de uma propen- 
são subjetiva. Ela deu grandes lucros, propiciou a prosperidade dos plantadores e comerciantes e, sem dúvida, o Brasil se fez com a escravidão.

O Brasil foi o país de mais prolongada escravidão nos tempos modernos. Tivemos 350 anos de escravidão aproximadamente e também fomos os maiores absorvedores de escravos da África. Avalia-se que chegaram ao continente americano 10 milhões de africanos escravizados. Quatro milhões vieram para o Brasil, ou seja, $40 \%$ do total de todo continente americano. Deve-se concluir que o Brasil foi o maior país escravista dos tempos modernos.

O fato da escravidão no Brasil me chamou muita a atenção e por isso me interessei em estudar esse assunto. Eu não podia aceitar a tese do Partidão, do qual eu era militante, de que o Brasil tinha sido feudal. Eu não encontrava elementos para confirmá-la.

Impressionou-me a força que a instituição escravista teve no Brasil. Daí a pesquisa que empreendi e que não deixou de despertar curiosidade e surpresa: como é que alguém, fora do meio acadêmico, se atrevia a abordar tema tão complicado?

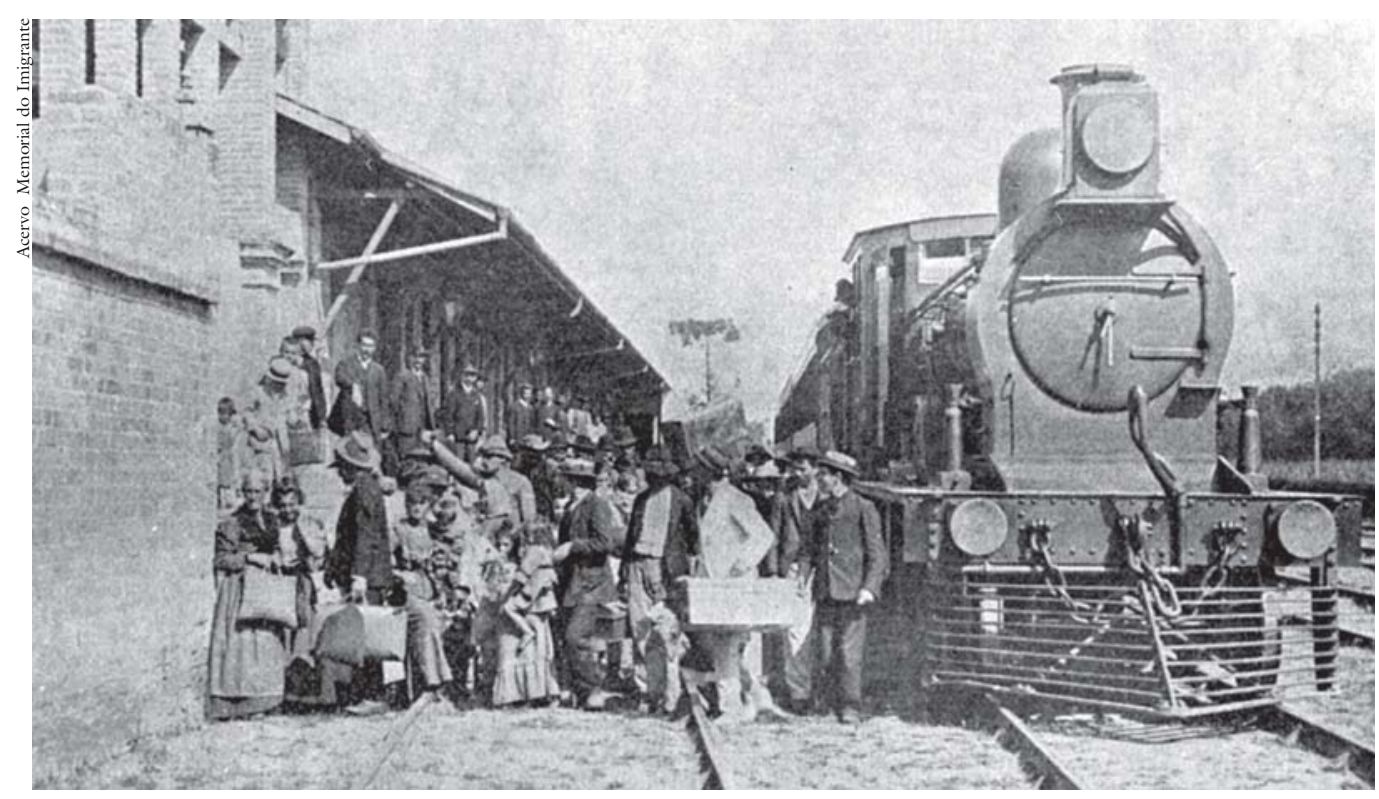

Desembarque de imigrantes na Estação da Hospedaria de Imigrantes em São Paulo, 1907.

ESTUDOS AVANÇADOS - A Abolição acompanhada do subsídio estatal dado à vinda dos imigrantes não teria sido uma espécie de indenização que o governo imperial, e depois o republicano, concedeu aos cafeicultores paulistas?

Jacob Govender - Pode-se dizer que a subvenção estatal dada à vinda dos imigrantes foi uma espécie de indenização do governo imperial para os cafeicultores. Foi uma espécie, não propriamente uma indenização, já que o dinheiro não foi parar no bolso dos cafeicultores. Deve-se observar que, pelo sistema vigente até o início da década de 1880, os imigrantes vinham com uma carga de 
dívidas intolerável, o que não os atraia. A imigração patinava e a subvenção governamental a alavancou.

Quando ficou claro que a escravidão tinha os dias contados, os imigrantes configuraram-se como a saída. A solução foi o Estado pagar as despesas, tornando mais atrativa a imigração. As estatísticas provam que a imigração deu, então, um salto. A partir de 1885, ela triplica e vai em progressão ascendente.

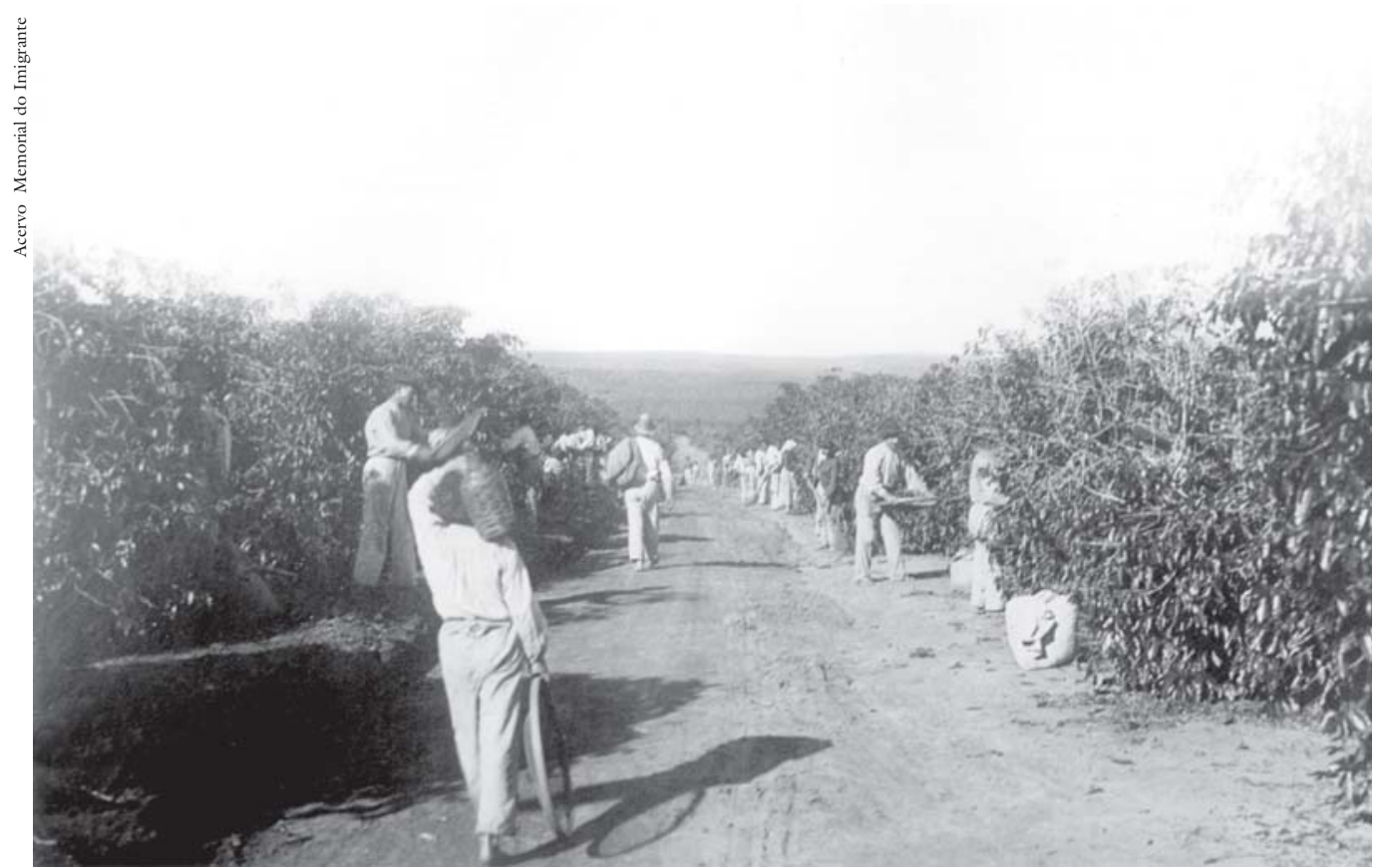

Imigrantes na colheita de café em fazenda no interior do Estado de São Paulo, 1920.

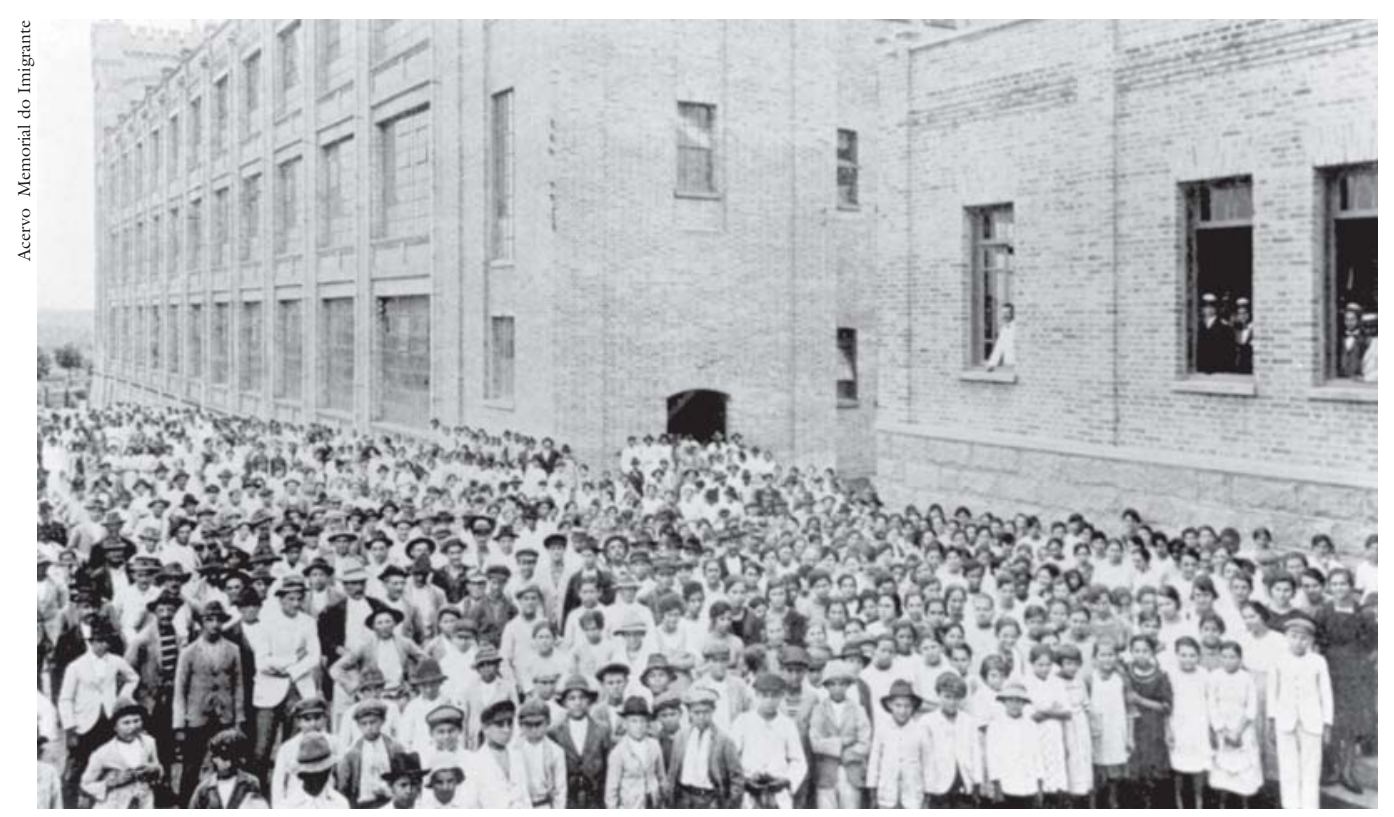

Homens, mulheres e crianças operárias da tecelagem Brasital, em Salto (SP), 1920. 


\section{Política internacional}

ESTUDOS AVANÇADOS - Pode-se afirmar que, nos últimos anos, vem ocorrendo uma direitização da política internacional?

Jacob Govender - Poderio e hegemonia não são termos equivalentes, mas devem andar juntos. Não acredito que a hegemonia americana esteja em declínio, como alguns afirmam, a exemplo de Wallerstein.

Quanto ao poderio, é indiscutível. Os americanos são hoje mais poderosos do que antes. São mais ricos e mais fortes militarmente. Desenvolveram a tecnologia militar mais que qualquer outra potência.

A hegemonia tem que ser avaliada de maneira relativa. O problema que se coloca é se os Estados Unidos têm hoje uma influência internacional maior ou menor. Na minha opinião, a influência nos últimos 20 anos aumentou. Até 1989, no tempo da Guerra Fria, é evidente que a Rússia era a adversária dos Estados Unidos. Hoje, ela está no campo da hegemonia americana, depende da boa vontade dos americanos no Fundo Monetário Internacional (FMI). A Rússia e as outras antigas repúblicas soviéticas, de adversárias e hostis que eram, hoje estão no campo da hegemonia americana.

A meu ver, a hegemonia americana se ampliou. A força da economia dos Estados Unidos, que concentra $30 \%$ do produto mundial, e a dependência que Japão e Alemanha têm do mercado americano, refletem essa hegemonia.

Quando vim trabalhar como professor visitante, aqui no Instituto, em 1994, me defrontei com a tese então difundida, por um número grande de autores, de que a hegemonia americana estava acabando e seria sucedida pela japonesa. Hoje verifico que isso não aconteceu. O Japão é que está amarrado aos Estados Unidos, tendo ingressado num período de estagnação que já dura 10 anos.

É certo que os EUA entraram este ano num período recessivo, que provavelmente possui caráter cíclico. Assim, a experiência pessoal me leva a desconfiar desse anúncio de que o império americano está acabando.

Mas, sem dúvida alguma, os Estados Unidos se enfraquecem com as agressões que cometem. Os americanos enfrentaram uma situação de derrota na Coréia, no Vietnã mais ainda, e agora estão sujeitos a um desastre se atacarem o Iraque. O mundo islâmico ficará mais hostil não só aos EUA, mas a todo o Ocidente. Uma rachadura imensa se abrirá no bloco ocidental. Já vimos que a Alemanha, a França e a Rússia não estão de acordo com a agressão ao Iraque, e Tony Blair aparece como um acólito submisso e desmoralizado.

Tais considerações me permitem passar à tese da direitização, que vem ocorrendo no cenário internacional. A partir de 1970, verifica-se uma ofensiva mundial das forças do capital contra as conquistas que o campo de trabalho conseguiu no pós-guerra, particularmente com o Estado do Bem-Estar Social. As descobertas da informática permitiram um enxugamento da mão-de-obra, sur- 
giu o chamado desemprego estrutural (não se falava nisso antes). Como houve um surto inflacionário nos anos 70 , o combate à inflação se fez principalmente mediante o arrocho dos gastos sociais.

O fenômeno foi bem tipificado pelos três estadistas emblemáticos da década dos 80: Reagan nos EUA, Thatcher na Inglaterra e Kohl na Alemanha. Essa tríade simbolizou bem as tendências direitistas dos anos 80 .

Depois disso, houve um interregno social-democrata, com o PDS de Romano Prodi, na Itália, o PS de Filipe Gonzalez, na Espanha, e o PS de Mitterrand, na França. Mas esse interregno também já acabou e hoje o quadro na Europa e nos EUA é de franca direitização. Nos Estados Unidos, Bush substitui Clinton, que não era nenhum anjo, mas que, comparado a Bush, até deixa saudade. E na Europa estamos vendo Chirac na França, Berlusconi na Itália, Aznar na Espanha, Haider na Áustria. Também Portugal, Holanda, Dinamarca e Bélgica estão com governos voltados para a direita. Certamente, não são de extrema direita, até o momento. Mas, de direita, de qualquer modo. Da direita que se convencionou chamar de civilizada. Somente na Suécia conseguiu manter-se a social-democracia, contrariando a maré direitizante.

Progredir para um mundo socialista, depois do desmoronamento da União Soviética e do desaparecimento dos regimes comunistas do Leste Europeu, não pode se dar sem levar em conta a direitização que se deu na cena internacional.

Isso se faz sentir aqui, na nossa América. No ano passado, o PRI, partido que dominou o México durante 60 anos, perdeu a eleição, porém, não para um partido de esquerda. Perdeu para o partido de oposição da direita de Vicente Fox. Na Argentina vemos toda essa turbulência do curralito, mas é uma situação de impotência sociopolítica, porque quem está no governo é o candidato derrotado nas últimas eleições. E agora ocore na Argentina algo realmente inusitado: o FMI, depois de meses de negociação, retira-se da Argentina sem conceder um dólar sequer. $\mathrm{O}$ que significa que os americanos estão se lixando para o que acontece com a Argentina.

Ainda há poucos meses, diante da debacle financeira que pairava sob o Brasil, o FMI concedeu rapidamente um empréstimo de 30 bilhões de dólares ao governo brasileiro. Se não foi tão prestativo com a Argentina - segundo maior país da América do Sul e praticante obediente de suas imposições -, somente se pode supor que a ruína dos nossos vizinhos não significa grande coisa para a superpotência do Norte. Mas, cedo ou tarde, ela aprenderá que superpotência não é onipotência. 